\title{
Inventiveness during Pandemic:Formulating and Translating Short Stories from Indonesian to Bangka Malay Language
}

\author{
Bob Morison Sigalingging ${ }^{1}$, Diana Anggraeni ${ }^{2}$, Herland Franley Manalu ${ }^{3}$ \\ \{bobsigalingging@gmail.com, dianaanggraeniubb@gmail.com, herland.franley@gmail.com\} \\ Department of English Literature, Universitas Bangka Belitung, Indonesia ${ }^{1,2,3}$
}

\begin{abstract}
Universitas Bangka Belitung compiled a book entitled Tata Kata: Kumpulan Cerita Pendek for primary school-aged children during a pandemic. The book contains several short stories on the theme of pandemics. This research aims at explaining the process of creating short stories and translating them from Indonesian to Bangka Malay language. This study utilizes a descriptive qualitative method. The researchers decided the data source, classified and analyzed the data, interviewed with open-ended questions and described the writing and translation process. The creation of the short stories was dominantly much influenced by seeking out the proper diction for those in 4-6 $6^{\text {th }}$ grade. Meanwhile, something prominent appeared during the translation process that the translators relied more on spoken language to translate. It was because of their difficulty obtaining the dictionary or good references to help them determine the equivalents.
\end{abstract}

Keywords: pandemic, short stories, translation, Bangka Malay language.

\section{Introduction}

The Covid-19 pandemic, in all of its manifestations, has altered the lives of Indonesians in a variety of ways. One of them is education. Indonesia's national education system, which was running safely and efficiently, suddenly had to turn the wheel 180 degrees to adapt and make peace with the situation. It was March 2020 when the emergence of Covid-19 took place. As the corona virus spread in Indonesia, the government developed educational policies tailored to the Covid-19 emergency status. These policies are still being implemented today, from primary education to higher education, with several developments and evaluations being carried out regularly to maintain educational quality in the face of adversity. Nizam [1] mentions policies involving higher education include: 1) the changing of face-to-face lecture to distance learning conducted from home, 2) lectures prioritizing digital media (fully online), 3) government assistance in the form of internet quotas for lecturers and students to support learning, and 4) the concept of hybrid learning.

The learning from the home program as one of the government's policies during the pandemic became an opportunity for a group of students of Universitas Bangka Belitung to demonstrate their natural creativity. They strove to advance further the reading literacy level of children, especially those aged $10-12$ years (4-6 ${ }^{\text {th }}$ grade). Referring to the Provincial Alibaca Index arranged by Puslitjakdikbud [2], reading literacy activity (Alibaba) in the Bangka Belitung Islands Province in 2019 showed a moderate level of $41.97 \%$. This fact was the primary motivation for them to formulate an alternative literary work to improve 
children's reading literacy in Bangka. Another supporting reason was that this fictional text, which was compiled by prioritizing culture and social issues, might help provide an experience of getting entertainment, enjoying stories, and contemplating, all of which can be obtained by children aged 10-12 years through searching, accessing, and finding explicit information from the content of short stories in the book so that the Reading Literacy Activity Index (Alibaca Index) of children is expected to increase even more.

The book Tata Kata: Kumpulan Cerita Pendek, written by the students of Universitas Bangka Belitung, is deemed qualified to represent the alternative material for having amusement and increasing children reading literacy. This book has ten short stories for children aged 10-12 years (4- $6^{\text {th }}$ grade). Some of them undertake pandemic as a theme. The short stories were composed in Indonesian and translated into English and Bangka Malay language. The product can then be utilized as additional reading material to improve children's reading literacy, introduce folklore, learn English, and preserve the local language. This work is also full of knowledge and moral messages or values embedded in the story content. It is hoped that the target readers will enjoy and appreciate this book as their literacy companion.

\section{Literature Review}

There have been relatively established either theories or studies in terms of reading literacy, short stories, and translation process. Leipzig [3] states that reading is a multidimensional activity that includes word recognition, comprehension, fluency, motivation, and fluency. Discover how readers use print to create meaning. Making sense of a pattern is what reading is all about. It necessitates recognizing the words in print, constructing an understanding, coordinating identifying words, and creating meaning such that reading is automatic and accurate. That is why the short stories in the book Tata Kata: Kumpulan Cerita Pendek are a valuable tool for children in $4-6^{\text {th }}$ grade to acquire all of the skills mentioned above.

According to Lazar [4], a short story is a work of fiction. It relates a single incident in great detail, discusses something at a critical juncture, introduces persons who are revealed to be fictional, and connects narrative and characters. Moreover, Pourkalhor and Kohan [5] claim that short stories could be beneficial since literature has the property of being universal, and short stories will allow the teacher to address human issues. Therefore, it is believed that a short story as a part of literary work will fully support its readers to increase their reading literacy or skill as long as it is arranged to present advantages to the target readers. Some benefits of short stories for children are namely:

1. Because they are brief and straight forward, short stories facilitate children's reading.

2. Because of their universal language, short stories are appropriate for multicultural settings.

3. Children gain a better understanding of other people and cultures through the reading of short stories.

4. Cultural awareness is increased through the use of short stories.

5. Short stories encourage children to be more creative and critical thinkers.

6. Short stories help children feel less anxious and more relaxed.

Furthermore, Sigalingging [6] defines that translation can be understood simply as a transfer of message using the equivalent word from the source language (SL) to the target language (TL). A translator must be fluent in two languages and two cultures. This is directly tied to the translator's duty for the translation's quality. It means the quality of the translation is 
reflected through the process. The translation is more than just transferring meaning from the source language (SL) to the target language (TL). Other factors to consider include lexical and grammatical elements, language style, and the author's intent when writing the source text [7].

In the context of the translation process, Bathgate [8] mentions several steps that the translator, namely, should pass:

1. Tuning It is to get the "feel" of the text to be translated. Translators must develop the language of a poet or novelist, lawyer or economist, research physicist or factory manager, advertising copywriter or biblical prophet, depending on their line of work. If the text is complex or is not familiar, it is advised that the translators read some background literature.

2. Analysis

Once the translators have "attuned" their minds, they are now ready to analyze the text-to split sentences into translatable units, words, or phrases.

3. Understanding

After putting the sentences into translatable units, the translators will put them together again in a form that they can understand and respond to emotionally.

4. Terminology

The next step is to consider the keywords, phrases, or other specific terminologies. In this step, besides having complete and various dictionaries, the translators should have a vast knowledge of both SL [Source Language] and TL [Target Language].

5. Restructuring

The translators must restructure the translation result by the rules of the TL. The translation should be readable and natural in the sense that it does not sound like a translation.

6. Checking

The translation process does not stop at restructuring. It also becomes the translators' job to check and recheck the translation result. The translators should be correct in grammar and other visual errors, such as punctuation, spelling, capitalization, etc.

7. Discussion

It is always advisable for the translators to discuss with other people during the translation process and after the translation is finished. Remember the saying: it is always easier to find one's mistakes than to see our errors. The translation should not be done in isolation.

Syed [9] thinks that literary translation is recognized as a necessary procedure through which the texts are imagined, created, and read. It is regarded as a highly artistic and creative discipline that necessitates careful attention. This concept strengthens the efforts of the students to produce a good translation quality of the short stories in the Bangka Malay language. A translator must comprehend the material to be translated. Understanding the material requires sufficient basic knowledge in the field of science concerned. As a result, a literary translator needs to have the ability to understand and appreciate an academic work.

The presence of local languages is critical to a society's ability to communicate. Bangka language is a part of the Malay cluster. The people of Bangka Island and the surrounding small islands communicate in Bangka Malay. Saputra and Afifulloh [10] explain that the Bangka Malay language in its development has been modified and has many variants. During this time, the Bangka Malay language developed and evolved by the people who spoke it. Several dialects of the Bangka Malay language exist, namely the Pangkalpinang, Sungailiat, Toboali, Mentok, and Belinyu dialects. Translating the short stories from Indonesian into 
Bangka Malay is an excellent way to preserve the local language. However, the Bangka Malay language has made significant contributions to the Malay and Indonesian people's civilization.

\section{Research Methods}

This study is descriptive qualitative research. A qualitative method was undertaken to provide a comprehensive description of the formulation and translation process of short stories from Indonesian into Bangka Malay language in the book Tata Kata: Kumpulan Cerita Pendek. Moleong [11] describes the method as the perfect procedure for attaining descriptive data from either written and spoken discourse and the behaviors of the participants observed from the existing phenomenon. This work aims at rendering a systematic and factual interpretation of the problem from the data obtained by presenting, analyzing, and lastly, interpreting the data [12]. Lincoln and Guba [13] defines the location of study as the focusdetermined boundary, the limit used to determine the focus or object of the study. Thus, location is not always geographic or demographic. A book also can be a research location.

The techniques applied in this study were observation, questionnaire, and interview. The researchers directly participated in the discussion by recording the student's answers to the prepared questions without taking part in the conversation. After gaining the data, the team asked the students or translators to fill out the online questionnaire. All was done to make sure the data obtained are valid. The data was collected through the printed book Tata Kata: Kumpulan Cerita Pendek. Respondents of this study involved the authors and translators of the short stories. The researchers, as well as the team behind data collection, are the instruments of this study. The team involved themselves in observing the bilingual short stories in Indonesian dan Bangka Malay language.

\section{Results and Discussion}

\subsection{Formulation of the Short Stories in the Book Tata Kata: Kumpulan Cerita Pendek}

Book Tata Kata: Kumpulan Cerita Pendek lists ten short stories compiled by the students of Universitas Bangka Belitung. They are Sepucuk Surat dari Piko Sang Kelelawar, Aku dan Loli, Awas, Ada Virus!, Legenda Akek Antak, Mbok Ratmi dan Ladang Bertuah, Nek Gergasi, Gila Belanja, Depati Iskandar, Bukit Tambun Tulang, and Dandi Si Hantu Bijak. Three short stories are related to a pandemic, the following three short stories are inspired by oral literature, and the last four short stories are fantasy.

01/AU-SA/TKKCP/INTR2020/A

(00:01:49-00:02:08)

"Sebagian dari tema cerita yang kami buat itu bertemakan Covid-19. Namun, ada sebagian juga yang bertemakan bebas seperti fantasi, cerita anak, yang intinya kayak lebih ke genre family atau keluarga. Seperti itu ..." (Indonesian transcript)

"Some of the story themes we created are Covid-19. However, there are also some free themes such as fantasy, children's world, which basically are more like family genres. Something like that ..." (translated) 


\section{2/AU-IRP/TKKCP/INTR2020/A}

(00:02:09-00:02:17)

"Terus juga ada beberapa dari cerita kami, ada dua atau tiga cerita yang menceritakan tentang legenda dan cerita rakyat Bangka Belitung." (Indonesian transcript)

"Then there are also some of our stories, two or three stories, tell about the legends and folklore of Bangka Belitung." (translated)

The short stories were originally written in the Indonesian language (Bahasa Indonesia) as the source language. The fiction was then scheduled to be translated into two target languages, namely English and Bangka Malay, to facilitate the children aged 10-12 years to increase their reading literacy and language skills.

In the beginning, the authors had to think hard about how to create all short stories with the Covid-19 theme to adjust to the current situation without feeling monotone. They were demanded to be creative. However, they eventually gave up and decided to present some alternatives beyond the pandemic theme.

\section{3/AU-IRP/TKKCP/INTR2020/A (00:03:08-00:03:35)}

“... karena dari awal kami kira tema itu harus hanya ke pandemi, jadi kami itu muter otak gimana caranya supaya sepuluh cerita itu bertemakan covid, tapi nggak monoton. Kayak gitu. Tapi ternyata setelah didiskusikan kembali, ternyata cerpennya boleh bertema bebas jadi kami agak juga berpikirnya juga ah bebas mau bikin cerita yang kayak gimana." (Indonesian transcript)

" ... because from the start we see the theme should only be for the pandemic, so we are extremely thinking on how to make the ten stories themed on covid, but not monotonous. Look simple. However, it turns out that after being discussed again, the short story can be freely themed so we also suppose that we have a freedom to make a story like that." (translated)

It was taken to avoid either writer's block or stagnation. They assumed that the essential thing is that the children will quickly understand the content and deal with the moral values inside the story. Indeed, the writer's block possibly made the authors not focus on the writing process.

04/AU-SA/TKKCP/INTR2020/A

(00:02:28-00:02:53)

“... Cuma kalau kendalanya itu lebih ke writer's block. Itu namanya itu WB. Kalau misalkan kita lagi kayak stag banget ga ada ide, nah di situ kalau misalkan mau ngetik cerita itu ga bisa fokus dan ga bisa konsen karena ga bisa dipaksakan." (Indonesian transcript)

"The one and only problem is likely writer's block. It is called WB. If, for example, we are stagnating, we don't have any ideas, so if we want to type a story, for example, we cannot focus and concentrate because you cannot force it." (translated) 
For the short stories inspired by oral literature such as Nek Gergasi, Legenda Akek Antak, and Bukit Tambun Tulang, the authors first surveyed several places in Bangka before creating them. This activity was organized to collect the accurate data used in the short stories. The information was derived from oral tradition. The informant was an older adult who is wellversed in myth or folklore.

\section{5/AU-B/TKKCP/INTR2020/A}

(00:05:13-00:05:26)

"Saya sempat berkunjung ke sana sebelum bikin cerpen ini dan kami juga sempat survei tempat-tempatnya tuh juga sudah pernah disurvei bersama dengan juru kunci dari tempat itu." (Indonesian transcript)

"I had visited there before making this short story and I also had a chance to survey the places, it has also been surveyed together with the caretaker from that place." (translated)

Illustrations are used to round out the book. Because the target readers were children aged 10-12 years (4-6 ${ }^{\text {th }}$ grade), the images were minimalist with two to three pictures to help children imagine the content of the short stories on their heads. They are helpful to construct children's critical thinking when analyzing each tale.

\section{6/AU-SA/TKKCP/INTR2020/A}

(00:05:29-00:05:53)

"Anak-anak yang usia dari 10-12 tahun mungkin bisa memvisualisasikan dalam kepala mereka dari ilustrasi yang ada di buku tersebut. Nah, jadi mungkin itu kayak lebih membantu proses berpikir anak juga, gimana cara mereka itu kayak menganalisis sebuah cerita atau pun kayak ngedapetin moral value dalam cerita tersebut." (Indonesian transcript)

"Children aged 10-12 years may be able to visualize the illustrations in the book in their heads. So, maybe it is more like helping children's thought processes too, how they do it, like analyzing a story or getting the moral values in the story." (translated)

\subsection{Translation Process of The Short Stories from Indonesian to Bangka Malay Language}

Translating is not always easy. Nababan [14] claims that the translation process has three stages, namely 1) analysis of source text (ST), 2) transferring, and 3) restructuring. When translating the short stories from Indonesian to Bangka Malay Language, the translators mostly meet obstacles in the second stage. In transferring, the translators are required to find the equivalent of the source language word in the target language. The process of transferring content, meaning, and the message is internal. The process takes place in the translator's mind. After the content, meaning and message are already in their mind, they then express it in the target language in writing. To obtain a better translation by the purpose of the translation itself, the translation needs to be harmonized.

07/TRL-SA/TKKCP/INTR2020/A

(00:08:14-00:08:26) 
“... pokoknya kayak agak canggung gitu menerjemahkan yang bahasa yang sering kita baca kan buku ceritanya kan bahasa Indonesia tuh tapi ketika kita nulis bahasa daerah, kayak aneh kesannya gitu." (Indonesian transcript)

"Basically, it is kind of awkward translating the language that we often read. The story book uses Indonesian language, but when I write the local language, the impression is that it looks weird." (translated)

Diction becomes the biggest problem in transferring stage. Not all words used by Bangka people in spoken language or daily conversation are equivalent to the terms in the source text. If applied, it will be weird. Therefore, the translators had to be very careful to choose and decide the appropriate equivalence.

\section{8/TRL-B/TKKCP/INTR2020/B (00:02:39-00:03:04)}

"Karena saya fokusnya menerjemahkan ke bahasa daerah, kadang juga terjadi apa ya, kesulitan untuk memilih diksinya itu, padanan katanya itu juga agak susah karena nggak semua orang paham tentang bahasa-bahasa daerah yang sudah apa, sudah lebih khusus gitu ga umum lagi bahasanya ..." (Indonesian transcript)

"Because I focus on translating into local language, sometimes what happens is the difficulty to choose the diction. The equivalent words are also a bit difficult because not everyone understands the meaning of local lexical, it should be more specific, it is not common anymore ..." (translated)

However, they seemed unfamiliar with the specific vocabularies in the Bangka Malay language that deserves to be used in the target text. The Bangka Malay language developed and evolved by the people who spoke it. Several dialects of the Bangka Malay language exist, namely the Pangkalpinang, Sungailiat, Toboali, Mentok, and Belinyu dialects. Every area has different local dictions. One word may produce different meanings based on it. For instance, the phrase besok page (tomorrow morning) can be translated into so pagi in Central Bangka Regency, but the word so means 'arrogant' in Pangkalpinang City.

\section{9/TRL-RA/TKKCP/INTR2020/B}

\section{(00:07:21-00:07:51)}

“... Terus ada juga kayak kata, perpadanan kata misalnya 'besok pagi'. Nah, 'besok pagi' itu kalau di bahasa daerah, kalau bahasa Bangka Tengah tuh, bahasa Bangka Selatan juga beda-beda kan kayak di Bangka Tengah itu kayak 'sok pagi' kalau besok pagi. Nah 'sok pagi' itu kalau di...misalnya dibilang ke bahasa umum daerah Pangkalpinang, kayak 'sok pagi' itu kayak sok, sok itu kayak menggambarkan sombong atau kayak beda makna." (Indonesian transcript)

"Then there are also words, equivalent words such as 'tomorrow morning'. Well, 'tomorrow morning' is in the local language, for Central Bangka, South Bangka is also different, like in Central Bangka, it is like 'sok pagi'. Now, if you say 'sok pagi', for example, it is said in the local language of the Pangkalpinang area, like sok pagi' is like pretentious, describing arrogance or having different meanings." (translated) 
This issue is crucial because of translators' difficulty getting an official dictionary of Bangka Malay-Indonesian or other printed supporting references. The translators need one until two days to finish their translation. They mostly rely on spoken language to transfer the message from Indonesian to Bangka Malay language. They tend to use 'general' dictions of the Bangka Malay language.

\section{0/TRL-RA/TKKCP/INTR2020/B \\ (00:07:08-00:07:12)}

"Kan bahasa daerah ini kan beda-beda nih, kan pengennya bahasa daerah itu yang umum." (Indonesian transcript)

"The local languages are different, right, I want the common local language." (translated)

\section{Conclusion}

To increase children's reading literacy in Bangka, the book Tata Kata: Kumpulan Cerita Pendek was created by a group of students of Universitas Bangka Belitung during a pandemic. Ten short stories are listed there and become alternative reading material for the children aged 10-12 years (4-6 $6^{\text {th }}$ grade). There are three themes applied in the short stories, namely pandemic, folklore, and fantasy. In making the short stories, the authors add illustrations to construct children's critical thinking when analyzing each tale. Meanwhile, in the translation process of the short stories, diction becomes the biggest problem in determining the equivalents in the Bangka Malay language. It is because the translators have lack strong and credible references to help them in translating. They mostly rely on spoken language to transfer the message from Indonesian to Bangka Malay language. They tend to use 'general' dictions of the Bangka Malay language.

\section{Acknowledgements}

We want to thank the Faculty of Social and Political Sciences and Institute for Research and Community Service Universitas Bangka Belitung, Indonesia, to fund this research and thank the team of researchers who were solid for conducting this research.

\section{References}

[1] Nizam. Paparan kebijakan pendidikan tinggi masa pandemi covid-19 [web pageonthe internet]. 2020 [cited 2021 July 1] Availablefromhttps://um.ac.id/info-akademik/paparan-kebijakanpendidikan-tinggi-masa-pandemi-covid-19/

[2] Puslitjakdikbud. Indeks Aktivitas Literasi Membaca 34 Provinsi. Jakarta: Pusat Penelitian Kebijakan Pendidikan dan Kebudayaan, Badan Penelitian dan Pengembangan, Kementerian Pendidikan dan Kebudayaan; 2019. p.58.

[3] Leipzig, D. H. What is reading [web page on the internet]. 2016 [Cited 2021 July 1] Availablefromhttp://www.readingrockets.org.

[4] Lazar, G. Literature and language teaching: A guide for teachers and trainers, Cambridge: Cambridge University Press; 1993. p.73. 
[5] Pourkalhor, O. and Kohan, N. Teaching reading comprehension through short stories in advance classes Islamic Azad University. Asian Journal Sciences and Humanities. 2013; 2(2):3.

[6] Sigalingging, B. M. Realization of decision making in the translation process of the web content of www.ayodya.com. Journal of Language and Literature. 2017; 5(2):98-108.

[7] Dewi, H. D. and Wijaya, A. Dasar-dasar penerjemahan umum. Bandung: Manggu Makmur Tanjung Lestari; 2020. p.6.

[8] Bathgate, R. H.A survey of translation theory" in Van Taal tot Taal. 1981; 25(2).

[9] Syed, S. Translating a literary text: enigma or enterprise. International Journal of English Language \& Translation Studies. 2017; 5(2):75-80.

[10] Saputra, P. P. and Afifulloh, M. Pemetaan penggunaan bahasa melayu bangka. KREDO: Jurnal Ilmiah Bahasa dan Sastra. 2020; 3(2):308.

[11] Moong, J. L. Qualitative research methodology. Bandung: PT Adolescent Rosdakarya Offset; 2007.

[12] Khasanah, I., Junining E., Rusmawati R. and Mauliddian K. The online use of language for communication in the tourist village community of Pujon Kidul Malang. In ISCS 2020. Proceedings of the $1^{\text {st }}$ International Seminar on Cultural Sciences; November 4, 2020; Malang, Indonesia. PAUL: EAI; 2020. p. 5.

[13] Lincoln, Y. S., and Guba, E. G., Naturalistic inquiry. Beverly Hills: Sage Publication Trans; 1985.

[14] Nababan, M.R. Teori menerjemah bahasa inggris. Yogyakarta: Pustaka Pelajar; 2003. 